\title{
RELIGIÃO DO ÊXODO. SOBRE O ATEÍSMO NO CRISTIANISMO DE ERNST BLOCH ${ }^{12}$
}

\author{
Beat Dietschy ${ }^{3}$
}

\begin{abstract}
Resumo
Ernst Bloch tornou-se conhecido na Alemanha como um dos mentores do movimento de 1968. O que é menos conhecido é que ele forneceu impulsos para a teologia política e, em parte, para a teologia da libertação. Seu livro Ateísmo no cristianismo: sobre a religião do êxodo e do reino, surgiu no ano de 1968; porém, como o próprio título já indica, não trata do movimento de protesto da época. $\mathrm{O}$ artigo quer mostrar como, mesmo assim, o livro e o seu ateísmo não ortodoxo puderam contribuir para a expressão das motivações centrais da revolta de então contra estruturas autoritárias e por uma nova cultura da vida. O faz partindo do Espírito da utopia, primeiro trabalho de Bloch, o qual há exatamente meio século já procurava fazer da resistência à guerra e ao capitalismo uma questão filosófica central. Na sequência, é perseguido como a revolução no "céu" da linguagem simbólica religiosa se associa com a crítica marxiana à religião e como, no contexto da tradição sóciorevolucionária de uma leitura herética da Bíblia, é trazida para o aquém. Conclui-se que a junção desses elementos possibilita a Bloch uma transformação da religião e sua reinserção em práxis libertadoras em busca do autoencontro humano. Por fim, será interrogado sobre a relevância de uma tal herança da religião para sociedades crescentemente pós-tradicionais. É apropriado se contrapor às fantasias de poder megalômanas de uma religião de mercado sem limites, que se espalhou na esteira das revoltas de 1968 ?
\end{abstract}

Palavras-chave: Des-teocratização. Tradição dos oprimidos. "Experimento do reino". 1968. Leitura subversiva da Bíblia.

\section{RELIGION DES EXODUS. ZU ERNST BLOCHS ATHEISMUS IM CHRISTENTUM}

\section{Zusammanfassung}

Ernst Bloch ist als einer der Vordenker der 1968er-Bewegung in Deutschland bekannt geworden. Er hat, was weniger bekannt ist, der politischen Theologie und teilweise der Theologie der Befreiung Impulse gegeben. Sein Buch „Atheismus im Christentum. Zur Religion des Exodus und des Reichs“ ist im Jahr 1968 erschienen, doch handelt es, wie schon sein Titel anzeigt, nicht von der damaligen Protestbewegung. Der Artikel will zeigen, in welcher Weise das Buch und sein unorthodoxer Atheismus dennoch zentrale Motive der damaligen Revolte gegen autoritäre Strukturen und für eine neue Kultur des Lebens zum Ausdruck verhelfen konnten. Er tut dies ausgehend von Blochs Erstlingswerk „Geist der Utopie“, das genau ein halbes Jahrhundert zuvor schon den Widerstand gegen Krieg und Kapitalismus zur philosophischen Hauptsache zu machen suchte. Weiter wird verfolgt, wie die Revolution im „Himmel“ der religiösen Symbolsprache sich mit der marxschen Religionskritik

1 Título original: Religion des Exodus. Zu Ernst Blochs 'Atheismus im Christentum'. Publicado em: FÜSSEL, Kuno; RAMMINGER, Michael (Org.): Zwischen Medellín und Paris, 1968 und die Theologie. Luzern / Münster: Edition Exodus-Verlag, Luzern und Edition ITP, Münster, 2009, p. 206-220. O resumo foi especialmente elaborado pelo autor para o presente texto (Nota do tradutor).

2 Rosalvo Schütz traduziu este artigo. Schütz é docente de Filosofia na Universidade Estadual do Oeste do Paraná - UNIOESTE. Bolsista de produtividade do CNPq. A tradução é um dos resultados do pós-doutorado na Pontifícia Universidade Católica do Rio Grande do Sul (PUCRS) de 2019 a 2020.

3 Doutor em Filosofia e teólogo. Foi o último assistente de Ernst Bloch, tendo contribuído na organização de obras do próprio Bloch. É integrante da Associação Ernst Bloch [Ernst-Bloch-Assoziation] e membro fundador da Sociedade Internacional Ernst Bloch [Internationale Ernst-Bloch-Gesellschaft]. Atuou como conselheiro e jornalista em projetos de desenvolvimento intercultural na América Latina. Foi docente de Ética na Suíça. Gerenciou a organização "Pão para Todos" e atualmente é presidente da organização não governamental Comundo, em Lucerna/Suíça, além de trabalhar no jornal Neue Wege (Novos Caminhos) de Zurique e participar de projetos de pesquisa sobre globalização, teologia da libertação e filosofia intercultural. Reside em Berna/Suíça (Nota do tradutor). 
verbindet und in der sozialrevolutionären Tradition häretischer Bibellektüre verdiesseitigt. Das Zusammengehen dieser Elemente, so die Konklusion, ermöglicht Bloch eine Transformation von Religion und ihre Wiedereinbettung in befreiende Praxen auf der Suche nach humaner Selbstfindung. Abschliessend wird nach der Relevanz eines solchen Religionserbes für zunehmend posttraditionale Gesellschaften gefragt. Ist es geeignet, den megalomanen Machtphantasien einer entfesselten Marktreligion entgegenzuwirken, die im Gefolge der Umbrüche von 1968 sich breitgemacht haben?

Stichwörter: Enttheokratisierung; Tradition der Unterdrückten; „Reichsexperiment“; 1968; subversive Bibellektüre

\section{Objetos perdidos $^{4}$}

El siglo veinte, que nació anunciando paz y justicia, murió bañado en sangre y dejó un mundo mucho más injusto que el que había encontrado. El siglo veintiuno, que también nació anunciando paz y justicia, está siguiendo los pasos del siglo anterior. Allá en mi infancia, yo estaba convencido de que a la luna iba a parar todo lo que en la tierra se perdía. Sin embargo, los astronautas no han encontrado sueños peligrosos, ni promesas traicionadas, ni esperanzas rotas.

Si no están en la luna, ¿dónde están? ¿Será que en la tierra no se perdieron? ¿Será que en la tierra se escondieron?

Galeano, 2008, p. 339.

I.

“68" atacou e abalou estruturas autoritárias. O protesto não se voltava apenas

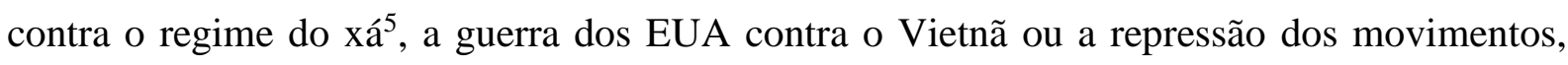
que eclodiam em todos os lugares, desde Berkeley e Berlim até Paris, Praga e México. E não acontecia apenas nas ruas e nos campi, pois a luta contra as autoridades tornadas suspeitas foi anunciada principalmente internamente, na arena simbólica. O que, acima de tudo, se tornou a marca registrada de "68" foi a revolução cultural, uma iconoclastia: hierarquias foram desencantadas, instituições questionadas e os pais desabonados. Isso não apenas pelos jovens de então: ao lado de Erich Fromm, Alexander e Margarete Mitscherlich, Herbert Marcuse e outros representantes da Escola de Frankfurt, também Ernst Bloch conta entre aqueles que prepararam o caminho para esse movimento. De Bloch, que na época tinha 83 anos, surgiu, no verão de 1968, a obra Ateísmo no cristianismo. No que segue, irei abordar esse livro para,

4 "OBJETOS PERDIDOS / O século XX, que nasceu anunciando paz e justiça, / morreu banhado em sangue e deixou um mundo muito mais injusto que o que havia encontrado. / O século XXI, que também nasceu anunciando paz e justiça, está seguindo os mesmos passos do século anterior. / Lá na minha infância, eu estava convencido de que ia parar na lua tudo o que na terra se perdia. / Porém, os astronautas não encontraram sonhos perdidos, nem promessas traídas, nem esperanças quebradas. / Se não estão na lua, onde estão? / Será que na terra não se perderam? / Será que na terra se esconderam?" Citado originalmente em língua espanhola, por isso também mantido na língua citada. Traduzido aqui na nota cotejado com Galeano, 2008a, p. 335 (Nota do tradutor).

5 Referência ao regime de Mohamed Reza Pahlevi, xá da Pérsia de 1941 a 1979 (Nota do tradutor).

\begin{tabular}{|c|c|c|c|c|}
\hline Qovista Dialectus & Ano 10 & n. 21 & Janeiro - Abril 2021 & p. $53-68$ \\
\hline
\end{tabular}


nisso, esclarecer o que há de emancipatório, mas, um pouco para além disso, também a limitação daquela revolta.

Enquanto teólogos críticos, como Helmut Gollwitzer ou a teologia da libertação concebida a partir do seu surgimento na época, se voltam para questões sociopolíticas Guerra do Vietnã, capitalismo, colonialismo, mudança de estruturas, evidenciamento de pobreza e dependência - para poder falar de Deus de modo legítimo, o marxista e ateísta Ernst Bloch faz justamente o caminho inverso. No seu livro, ele faz da inversão e da subversão no céu o seu tema, toma o 'acima' em seu cerne: os poderes nos quais se acredita e que autorizam o domínio dos senhores terrenos.

A situação motivacional é claramente a dos " 68 ": "Mas algo insatisfeito quer andar de modo ereto [...]. O melhor de hoje é sensível contra os senhores instituídos sobre nós" (Bloch, 1977, p. 17), consta logo no início. Com a adição da frase subsequente, é claro: "o que também tem consequências para algo instituído ainda mais acima". Nesse livro, portanto, será sacudida a imagem de Deus e isso já indica o conceito combativo de ateísmo no título. Hoje, em tempos de instrumentalização política da religião e de seu simultâneo reavivamento não crítico, tal debate seria ainda mais apropriadamente premente.

II.

Ernst Bloch trabalha na elaboração de Ateísmo no cristianismo desde 1966. Trabalhos prévios remetem até o tempo do exílio americano (1938 até 1949). Questões da religião, no entanto, já o ocupam desde sua primeira obra principal: Espírito da utopia. Esse livro, escrito no período da I Guerra Mundial, durante sua emigração suíça, originalmente tinha sido concebido enquanto "sistema do messianismo teorético". E mesmo em sua estrutura final o apocalipse e a questão de Deus tomam lugar central. É o protesto filosófico da década expressionista, um manifesto contra o tempo oco e o vazio de sentido, contra a guerra e o capitalismo.

Espírito da utopia é uma rebelião contrafactual, um livro de resistência contra o declínio de uma civilização que ao menos ainda foi adornada com ideais e valores. É compreensível apenas ante o pressuposto de um mundo em desmoronamento e que arrasta consigo para o abismo o seu criador e tudo o que se acreditava antes deste, de modo que “natal, páscoa e pentecostes nos apareçam como uma única sexta-feira santa, como sendo nosso triste saber de que o redentor faleceu, mas de tal modo como se ele já tivesse sido assassinado na manjedoura" (Bloch, 1977c, p. 362). Em face desse abandono divino, Bloch

\begin{tabular}{|l|l|l|l|l|}
\hline Q & Ano 10 & n. 21 & Janeiro - Abril 2021 & p. $53-68$ \\
\hline
\end{tabular}




\section{RELIGIÃO DO ÊXODO. SOBRE O ATEÍSMO NO CRISTIANISMO...}

foca naqueles que foram dessa forma abandonados, os únicos ainda capazes de levar até o fim a faísca messiânica: “Os seres humanos ainda estão [...] definitivamente desprotegidos e sem céu, mas em nossa força para virar e clamar, em nossa mais profunda e inominável interioridade, está adormecido um Cristo desconhecido, vencedor da frieza, do vazio, do mundo e de Deus" (1977c, p. 332).

Espírito da utopia é perpassado por uma teúrgica magia dos desejos: “O desejo edifica e constitui algo real, apenas nós mesmos somos os jardineiros da árvore misteriosa, a qual deve crescer" (Bloch, 1977c, p. 341). Esse poder de realização do sujeito também se estende ao tornar-se real do que se tornou ausente, daquilo que foi outrora chamado de ens realissimum Deus. Bloch fala de um "Deus hesitante ante sua transformação em espírito santo" e da, daí necessariamente decorrente, "força de nominação, do ateísmo heroicomístico" (1977c, p. 230). Aí se anuncia uma terceira época do "espírito", a qual, diferente do que em Joaquim de Fiore, não subdivide apenas as épocas históricas das igrejas, mas as compreende como estágios de transformação do próprio Deus, de pai em filho e deste em espírito. Bloch conecta a teologia histórica do abade calabrês com pensamentos oriundos da mística judaica, interligando o Espírito Santo com a Shekhinah, que é aquela presença ou "habitação de Deus" que acompanha o povo errante de Deus pelo exílio.

No Espírito da utopia, o socialismo é uma "forma de organização do não essencial" para a solução da problemática econômica, pré-estágio para uma - futura, escatológica - igreja, na qual a Shekhinah sem lar específico possa, por assim dizer, vir para casa. No entanto - assim se encerra o capítulo do "pensamento socialista" com uma citação do Baal Shem ${ }^{6}$ - o messias só poderia vir quando todos os convidados estivessem sentados à mesa. "Essa", enfatiza Bloch, "é primeiramente a mesa do trabalho, e só então a mesa do senhor" (1977c, p. 411).

No decorrer dos anos 20, a "mesa do trabalho" e sua organização, no contexto da recepção de Marx e Hegel iniciada por Lukács, irão se tornar cada vez mais importantes para Bloch. O autoencontro de um sujeito imaginado no obscuro do instante vivido não mais ocupa um espaço amplo, cedendo lugar para a história e a sociedade como espaços processuais dialeticamente mediados entre sujeito e objeto. O problema do obscuro do agora vivido, portanto, também é interpretado como historicidade presente não conceituada. O sujeito ativo se torna a alavanca e o motor dos acontecimentos históricos na medida em que compreende o

6 Referência a Baal Shem Tov, fundador do movimento místico do Chassidismo (Nota do tradutor).

\begin{tabular}{|l|l|l|l|l|}
\hline Qevista Dialectus & Ano 10 & n. 21 & Janeiro - Abril 2021 & p. 53 - 68 \\
\hline
\end{tabular}


presente como tendência, isto é, lugar de mediações amplamente ramificadas, de decisão e do "nascimento do novo" (Dietschy, 1988, p. 66).

Também na obra tardia as protuberâncias esperançosas do Espírito da utopia continuam visíveis. No entanto, aí elas são envolvidas com mais força numa análise teóricosocial e crítico-ideológica, a qual Bloch nomina de "corrente fria". O ato analítico das situações e condicionamentos é para estar acompanhado do ato "prospectivo-entusiástico", a "corrente quente" e, assim, fundamentar uma teoria-práxis “concreto-utópica". Com isso, algo da exuberância apocalíptica da obra da juventude é suavizado; a intenção fundamental, no entanto, é preservada. Quase todas as obras de Bloch continuam tendo um capítulo final que se ocupa das grandes questões do 'para onde' e 'para quê', do entusiasmo final pela vida e da "foz" esperada.

Acima de tudo, Bloch mantém despertas as lembranças de sonhos de movimentos reprimidos, que, em sua maioria, foram banidos para heresias. $\mathrm{O}$ espírito rebelde de um Thomas Münzer, para o qual - após o fracasso de uma revolução na Alemanha em 1921-, Bloch dedica um livro, é um exemplo paradigmático para tais "subterrâneos celestes" (1977, p. 206). É algo que continua tendo efeito, enquanto protesto, como "consciência de tudo aquilo que não aconteceu [...], no interior daquilo que já aconteceu" (1977, p. 14), mesmo que, por vezes, também de forma pervertida, como no caso do mito nazista do terceiro reino. Sonhos social-revolucionários, cujos caminhos foram bloqueados na realidade, muitas vezes sobrevivem na memória dos povos em estruturas mítico-religiosas. Bloch advoga, especialmente na obra Herança de nossa época (1935), a favor de um tratamento crítico de tais histórias inacabadas e de um "transformar dos inícios míticos em efetivos" (1977a, p. 66).

Também no passado há futuro, o qual aguça nosso olhar para as direções dos objetivos de um presente posterior. Nisso Bloch também insiste. No livro sobre Münzer, ele escreve sobre isso:

Ainda inaudita, a história subterrânea da revolução aguarda sua obra, já iniciada no curso correto; mas os irmãos do vale, os cátaros, os waldenses, os albiguenses, o abade Joaquim de Calábria, [...] Münzer e os batistas, Sebastian Franck, os iluminados, Rousseau e a mística humanística de Kant, Weitling, Baader, Tolstói todos eles se unem e a consciência dessa fantástica tradição troveja de novo contra o medo, o estado, a descrença e contra os altos poderes desumanos (Bloch, 1973, p. 206-207). 
Seria um acaso que Bloch se disponha novamente numa época como os anos sessenta, que está em ebulição e onde ainda se prenuncia um protesto difuso, a escrever um livro justamente sobre o religiosamente transmitido (no qual os nominados espíritos de liberdade novamente assumem um papel proeminente)? De qualquer forma, em uma carta endereçada ao economista Adoph Lowe, no qual anuncia o livro sobre ateísmo a ele dedicado, Bloch comenta que sobre o fator objetivo, isto é, sobre a tendência social, estaria repousando uma neblina, também perceptível "na definição dos objetivos do atual grandioso movimento estudantil internacional”: "Os objetivos anunciados como a abolição do paternalismo e da fúria autoritária dos 'idiotas especialistas', ou mesmo em algo tão palpável como no aniquilamento dos crimes hitleristas dos americanos no Vietnã (amerikanischen Hitlerverbrechen)", lhe pareciam "representações de encobrimento para algo outro, porém ainda intencionado de modo difuso" (Bloch, 1985, p. 803). Ateísmo no cristianismo, de qualquer forma, tenta identificar linhas de êxodo e intenções finais.

\section{III.}

Ateísmo no cristianismo resume o que Bloch já havia exposto em diversas outras obras sobre a relação entre religião e esperança. No entanto, dessa vez se concentra na linha da tradição bíblica com a qual seu materialismo utópico, apesar de toda a ruptura epistemológica, se vê especialmente interligado. Diferentemente de no Princípio Esperança, aqui as religiões não bíblicas recebem pouco espaço. Não se trata de história da religião, mas sim de extrair da religião aquilo que nela há de libertador e orientado ao alvo (Zielführende). $\mathrm{Na}$ "religião do êxodo e do reino", como indica o subtítulo, encontra o eixo semântico que demarca a herança bíblica à luz de sua história de efeitos inconclusa. Em decorrência disso foi acusado de uma "exegese selvagem" (Donner, 1971, p. 420) ${ }^{8}$, no que, porém, foi deixado de perceber que, sem modelos interpretativos alternativos, as histórias oprimidas de liberdade não podem pré-aparecer. A Bíblia não foi escrita pelos próprios pobres. Além disso, princípios interpretativos que sigam os da linha do êxodo já estariam pressupostos numa hermenêutica imanente da bíblica (cf. Croatto, 1989). Que uma tal releitura da crença bíblica dê certo a um não teólogo e não partidário religioso é o que constitui o encanto especial de Ateísmo no cristianismo.

7 Bloch compara a Guerra do Vietnã com Hitler. (Nota do tradutor: Nota elaborada a partir de esclarecimento dado pelo autor).

8 Compare também Martin, 1975, p. 420 ss.

\begin{tabular}{|l|l|l|l|l|}
\hline Q & Ano 10 & n. 21 & Janeiro - Abril 2021 & p. 53 - 68 \\
\hline
\end{tabular}


Aqui não é o lugar para esboçar o conteúdo, a construção e a recepção do livro. Me limitarei a quatro áreas, as quais me parecem ter maior valor reflexivo no contexto e atualidade dos "68": a crítica da religião, abarcando a questão do ateísmo; o criticamente salvável; o pensamento do êxodo; e o sujeito de uma práxis de fé libertadora.

\section{A crítica da religião}

“O chefe é 'ex’, para o de cima veio um golpe devastador” (Bloch, 1977, p. 38): isso pode ser tomado como conclusão da desvalorização social do céu pela modernidade burguesa e seu iluminismo. Porém, há aí algo mais. A negação de um "lá em cima, no qual o ser humano não aparece", para Bloch, tem o mesmo significado com aquilo que já foi realizado no antigo esclarecimento e na crítica da religião, quando da expulsão do medo diante dos deuses. Ela é uma libertação: "O conceito de ateísmo", assim consta no Princípio Esperança, está como algo positivo para o "reino da liberdade" (Bloch, 2006, p. 377).

Também no interior da religião bíblica acontece o enfrentamento com um Deus despótico e causador de medo. De forma mais clara em Jó, mas também em muitas passagens distorcidas ou desfalcadas, como aquelas dos "resmungos" dos filhos de Israel (cf. Ex.: 14,11; 17,2; Num.: 11,4-9; 20,2-6; Salmos.: 95,8-11; 106,16-39) ${ }^{9}$, por detrás dos quais se escondem queixas legítimas do povo. Daí conclui Bloch que "ler a bíblia sub specie, desde sua história herética e ainda atuante é, inclusive analítica e detetivescamente, necessário" (Bloch, 1977, p. p. 23). No "lá em cima", contra o qual a revolta dos escravos se dirige, na maioria das vezes está contido o mito astral, que está ancorado em todas as culturas pré-asiáticas e é fundador de hierarquias. A fé no êxodo não suporta isso.

"Filho do homem - Terra do Egito" (cf. Bloch, 1977, p. 104) é a antítese pela qual Bloch reconstrói criticamente a tradição bíblica: consequentemente, ele também descobre algo faraônico nas imagens divinas, e não apenas elementos do êxodo: "Filho do homem" refere-se ao eixo de "nossa crescente autoinserção nos segredos religiosos diante de nós" (1977, p. 110), a qual Bloch encontra especialmente na mensagem jesuânica. Diferentemente do título senhoril Kyrios, que estabelece analogias com o imperador romano e tem significado de culto, Bloch vê no "filho do homem" apocalipticamente carregada a expressão autocompreensiva de Jesus: é assim que se apresenta “o senhor, que nem mesmo quis ser um” (1977, p. 207).

9 Referências bíblicas inseridas pelo autor apenas para a versão atual do texto, a fím de exemplificar e clarear do que se trata (Nota do tradutor).

\begin{tabular}{|l|l|l|l|l|}
\hline Q & Ano 10 & n. 21 & Janeiro - Abril 2021 & p. $53-68$ \\
\hline
\end{tabular}


Esse eixo antiteocrático perpassa toda a Bíblia, conduz desde o Eritis sicut deus da cobra do paraíso "até o filho do homem e seu trono celeste não transcendente, mas de um reino escatológico", o que, para Bloch, configura "a Bíblia pauperum real” (Bloch, 1977, p. 110). O fato de ele ter sido encoberto e desativado por uma igreja de senhores torna necessário o trabalho de reconstrução detetivesco-detectante. $O$ vestígio-exôdo da “desteocratização" primeiramente precisa ser exposto, o que é possível na medida em que é questionado desde o ponto de vista de uma vontade transformadora e libertadora. Com isso Bloch se aproxima daquilo que, desde os anos 70, vinha sendo trabalhado na exegese feminista e que também opera com uma hermenêutica da suspeita. Ele certamente teria tido interesse na crítica Kyriárquica de uma Schüssler-Fiorenza e poderia ter aprendido dela algumas diferenças de gênero no que diz respeito ao acesso hermenêutico à Bíblia e à religião. De qualquer modo, ele identifica nos profetas - em Jó e especialmente no Novo Testamento (João: 15, 21) - vestígios de um Deus desconhecido, o qual, apesar de "toda forma do Deus dos senhores (mesmo que sem uma imagem visível do ídolo) acerta no centro do Kyrie" (Bloch, 1977, p. 216).

Bloch também compartilha com a teologia feminista a crítica à teoria da morte sacrificial, a qual ele identifica como um retorno a uma imagem bárbara e canibalesca de Deus. No entanto, ele não rejeita a teologia paulina em toda a sua extensão: "É certo que não somente a teologia da morte-sacrifício provém de Paulo, mas também o mistério-esperança configurado em torno da ressureição: com ela é introduzida a aniquilação dos poderes que dominam o eon presente e, assim, o crepúsculo de uma nova criação” (Bloch, 1977, p. 189).

O tipo de crítica blochiana da religião bíblica é de uma permanente atualidade e, ainda que seja possível menos desde o material concreto do que do procedimento, ela implica, também metodicamente, um "transcender" em vez de "transcendência". Ela requer uma vontade de mudança, mas não aquela que muitas vezes pode ser constatada tanto nos crentes quanto naqueles que desprezam a religião. Bloch se manifesta tanto contra os princípios do "está escrito" quanto do "o partido sempre tem razão": "Quanto mais cômoda, obstinada e firmemente se acreditava em uma posição que apenas precisava ser aprendida de cor, tanto mais amargamente ela é suspensa, quando, nem que seja apenas uma de suas partes, vem abaixo". Todo esse tipo de posição não suporta choque algum. "Em contraposição, a posição real só pode prosperar quando se está em busca, no pressentimento não decepcionado, na fidelidade ao caminho e de seus sinais" (Bloch, 1977, p. 312).

\begin{tabular}{|c|c|c|c|c|}
\hline Qovista Dialectus & Ano 10 & n. 21 & Janeiro - Abril 2021 & p. $53-68$ \\
\hline
\end{tabular}


Em decorrência disso, pode-se dizer que o ateísmo significa dizer não a senhores celestes, mas também à coisificação de processos abertos de futuro. Ele objetiva um "sujeito que, para além do medo da transcendência, livrou-se também da quimera da transcendência e, inclusive, do patriarcalismo hipostasiado" (Bloch, 1977, p. 315). Transcender sem transcendência significa esperançar. "Onde há esperança também há religião, mas onde há religião nem sempre há também esperança, ou seja, nem sempre ela é ideologicamente transplantada, construída de baixo para cima" (Bloch, 1977, p. 346). E é por isso mesmo que se faz necessária a crítica à religião. Uma crítica que dissolva tanto o caráter senhoril e o medo dele, quanto a coisificação e o poder da facticidade, pois, diz Bloch com o olhar sobre tantos decretos e cartas pastorais, "os pastores amavam prestar homenagem àquele poder que havia crucificado o primeiro herege cristão: pois frequentemente era seu próprio poder" (1977, p. 348).

\section{2. $\quad$ Crítica salvadora}

Não são apenas escombros que sobram do desmonte do "lá em cima" empreendido por Bloch. Ele destrói as hipóstases celestes, para, como afirmou o jovem Hegel, reivindicar para os seres humanos os tesouros desperdiçados no céu. Isso significa algo mais do que uma troca de endereço, o qual, assim como em Ludwig Feuerbach, apenas reconduz os seres divinos de volta às projeções humanas dos desejos. Justamente nos "“tesouros” cristãos contidos no cofre do além" (Bloch, 1977, p. 285) está contido, segundo Bloch, algo que se difere do ser humano agora existente. Importa fazer esse algo diferente se efetivar.

Por isso, em Ateísmo no cristianismo não há muito espaço para uma crítica à Bíblia que tenha em vista apenas a adaptação à visão de mundo moderna e, como em Rudolf Bultmann, busque apenas demover cientificamente aquilo que é místico. Se de fato a mensagem deva ser uma boa nova para os fadigados, sobrecarregados, humilhados e insultados, então não deve acontecer des-mitologização (Entmythologisierung) mas a desteocratização (Enttheokratisierung).

Bloch não procede uma negativa ao trono divino a fim de criar espaço para um domínio racional. Isso o fazem, como mostra Franz Hinkelammert, as revoluções burguesas: "No lugar do céu no além elas introduzem o progresso sem fim, o qual resulta de uma aliança entre empresas e tecnologia, fábricas e laboratórios. Elas desenvolvem uma religião inerente ao mundo [...]. Essa transcendência externa à vida humana força um alinhamento tenso em relação ao futuro que não permite mais trégua alguma" (Hinkelammer, 2007, p. 371). 
Bloch não confunde esse progredir de uma "má infinitude" com a utopia que incita para o concreto, o presente e a realização. Da mesma forma, sua revolta contra o céu dos tronos não pode ser reduzida a uma simples revolução palaciana. Ela não substitui simplesmente um domínio que precisa de sacrifícios por outro, mas intenta o fim da dominação e da submissão no sentido cristão originário. Por isso a crítica blochiana da religião pode ser identificada não como aquela que quer negar as promessas religiosas oferecidas, mas sim que quer realizá-las: "Somente um ateu pode ser um bom cristão, mas certamente também apenas um cristão pode ser um bom ateu” (Bloch, 1977, p. 24).

\section{A saída (Der Auszug)}

A Bloch foi atribuído um “ateísmo, pelo amor de Deus!” (Steinacker-Berghäuser, 204, p. 146). De fato, no Espírito da utopia ele caracterizou o abandono como sendo uma "forma terrível de ser envolvido por Deus" e referiu-se ao ateísmo "como uma piedade tremenda, do mais fervoroso amor divino" que livra esse mundo de Deus e o mantém puro (Bloch, 1977c, 341). Contudo, Bloch não permanece nisso. Desde a origem, seu ateísmo não é estático e sim rebelde, transformador e marcado pelo êxodo.

Bloch não apenas insiste na conhecida diferença entre o "pensar histórico, prometeico e novum (Novum-Denkens)" hebraico (1977, p. 85) e o pensar-ser (Seins-Denken) grego. Ele tem um olhar para o que há de mobilidade na imagem bíblica de Deus, explicitando as rupturas e alterações. "A antiga figura de Javé, apesar de ser rica em recaídas em déspotas orientais", mostra, no entanto, que, muito diferente de Zeus, posto como imóvel, há "lugar para mudança, andar junto, peregrinar das características" (Bloch, 1977, p. 123). O fumegante Deus vulcânico será indicativo de saída e modelo não apenas moral, mas também de Futurum ("Eu serei aquele que me tornarei”): "Moisés evoca este símbolo surgido, como aquele que 'indica o caminho para fora da servidão', como bandeira e horizonte das expectativas da libertação" (Bloch, 1977, p. 124).

No entanto, a simples purificação da imagem de Deus, uma "saída da concepção cesarista de Deus" (Bloch, 1977, p. 165), ainda não é suficiente. Ele aplica o paradigma do êxodo ao próprio Deus do êxodo e fala de uma saída não apenas de todas as representações divinas até aqui, mas também dela mesma.

Para Bloch, o motivo principal para essa ruptura radical com aquilo que é indicado por "Deus" é a experiência fundamental de Jó, que já havia marcado o caráter

\begin{tabular}{|l|l|l|l|l|}
\hline Q & Ano 10 & n. 21 & Janeiro - Abril 2021 & p. $53-68$ \\
\hline
\end{tabular}


pessimista de mundo de sua obra juvenil: Deus se contradiz no seu agir. Daí se origina a separação, até mesmo a contraposição, à qual ele se vê forçado a fazer, entre o criador e o salvador do mundo: um princípio que conduz ao mau mundo disponível não pode ser o mesmo que o redime e o conduz para além dele (cf. Bloch, 1977, p. 61). Jó, em quem a teodiceia se quebra, no entanto, se torna o ponto da virada libertária, pois aqui é feita a seguinte descoberta: "Um ser humano pode ser melhor, comportar-se melhor que seu Deus" (Bloch, 1977, p. 150).

\section{O sujeito}

"A categoria originária da saída (Auszug) continua aqui trabalhando na transformação mais poderosa", assegura Bloch. "Depois do êxodo de Israel para fora do Egito, de Javé para fora de Israel, acontece agora um êxodo de Jó para fora de Javé; certamente: mas, para onde?” (Bloch, 1977, p. 152). Em Bloch, por fim, Deus passa por uma mutação para um reino, um reino de Deus sem Deus. Assim, normalmente, é expressa a resposta teológica quanto a essa saída da ideia de Deus, algo que cheira a uma secularização desajeitada do religioso.

De fato, Ateísmo no cristianismo cita a frase do Princípio Esperança: "A verdade do ideal de Deus é constituída unicamente pela utopia do reino" (Bloch, 1977, p. 218/Bloch, 2006, p. 374). Mas também aqui não é intencionado um simples golpe contra tudo. Aquele que leva em conta apenas o vazio que a negação do senhor celeste deixa para trás não percebeu a questão central. As categorias, na forma como Bloch as emprega, são carregadas de conteúdo e, por isso, "figuras tensionantes, figuras-tendência no processo", e não ideias platônicas ou essências firmes e bem acabadas. Elas são, como é assegurado em Experimentum Mundi, “estruturas dialéticas saídas de si mesmas" (Bloch, 1977b, p. 165). Nesse sentido é que pôde afirmar - de Jó - que justamente esse rebelde detém "confiança em Deus, sem acreditar em Deus" (Bloch, 1977, p. 165); ou, ainda, de modo novamente paradoxal: "aquilo que é pensado como o Deus do êxodo adquire uma validade do filho do homem (Menschensohn-Geltung), sem Deus" (Bloch, 1977, p. 206).

É justamente isso que indica a direção para a qual a ideia de êxodo conduz, caso ela permaneça coerente: não um reino que se pareça com um império, mas um que tenha afastado de si tudo o que é despótico, na medida em que o messias, filho do homem, não persegue um restabelecimento do reino de Davi com seu Deus senhor. Afirma-se muito mais

\begin{tabular}{|c|c|c|c|c|}
\hline Qovista Dialectus & Ano 10 & n. 21 & Janeiro - Abril 2021 & p. $53-68$ \\
\hline
\end{tabular}


como novo "êxodo escatológico-derrubante - em Deus enquanto ser humano" (Bloch, 1977, p. 183). O "derrubante" (“Umwerfende”), a intervenção humana em Deus - "um tribuno se senta agora sobre o trono e, assim, o suprime" (Bloch, 1977, p. 227) -; portanto, está participando do reino que está fundando. Simultaneamente, no entanto, ele, como reino da liberdade dos filhos de Deus, carrega consigo os traços de sua origem.

Portanto, também não é de ser entendido como secularismo raso, e sim enquanto coincidência significativa, quando Bloch destaca que "o especificamente humano e o materialismo irrompem ambos na transcendência divina" (1977, p. 303). Nesse sentido, pôde afirmar que "um impulso de Cristo pode viver, mesmo que Deus esteja morto" (Bloch, 1977, p. 231). Mística e materialismo encontram-se nisso que, assim como no Der Grüne Heinrich de Gottfried Keller ${ }^{10}$, onde a dissolução da religião feuerbachiana encontra-se com Angelus Silesius e seu "Eu sei que sem mim Deus não pode viver nem um instante/Se eu desapareço, ele deve, por necessidade, abrir mão de seu espírito" (Bloch, 1977, p. 283).

O livro não desemboca, portanto, em um ateísmo sem fé - não é por nada que seu título é Ateísmo no cristianismo - e sim, muito antes, numa fé libertada. Nas palavras de Bloch: "justamente quando os Deuses-tabu (Tabugötter) do medo tenham desaparecido, e justamente por terem desaparecido, revela-se o segredo adequado ao ser humano destemido" (1977, p. 317).

É esse segredo que Bloch persegue quando destrincha os sonhos diurnos e as formas de expressão da vida cotidiana ou as imagens dos desejos de momentos de completude na música, ou quando investiga poesia e religião, ou mesmo quando se volta para os fenômenos naturais ou, ainda, quando busca entender categorialmente o mundo como um experimento incompleto, que não foi concluído. Com a variação de uma expressão de Agostinho, Experimentum Mundi é concluído justamente com a frase: "Natura naturata nos ipsi erimus" (Bloch, 1977b, p. 264) ${ }^{11}$. O “encontro com o nós" é buscado nisso tudo, e o experimento mundo, em último caso, como "experimento do reino" (Bloch, 1977b, p. 228). Entretanto, seria simplório demais considerar a linguagem apocalíptica de Bloch apenas enquanto uma relíquia. O material linguístico tem força simbólica, funciona como indicação de caminho e sinal de reconhecimento para o ainda tão indeterminado do futuro, que está sendo buscado. É significativo que Bloch, de qualquer modo, chegue a afirmar, referindo-se

10 Trata-se do romance de Gottfried Keller, intitulado Der Grüne Heinrich, publicado pela primeira vez em 1855 (Nota do tradutor).

11 Agostinho havia dito: dies septimus nos ipsi erimus, nós mesmos somos o sétimo dia da criação.

\begin{tabular}{|l|l|l|l|r|}
\hline Q Rovista Qialectus & Ano 10 & n. 21 & Janeiro - Abril 2021 & p. 53 - 68 \\
\hline
\end{tabular}


ao mistério humano não resolvido (ungelüfteten), que "este é chamado, tanto no cristianismo como também no post Christum de - nosso Reino" (1977, p. 327).

IV.

Do que Ateísmo no cristianismo nos lembra hoje? Certamente de que, justamente num contexto crescentemente pós-cristão e pós-moderno, com uma religiosidade difusa e sem contornos, poucas vezes relacionada com recomeços, mas, muito mais, com necessidades de segurança, um embate crítico com a religião é do mais alto significado. Nós podemos aprender com Bloch que se trata, sim, de saber de qual tipo de trilha divina tem continuidade aí. O que reivindica autoridade em nossa atual sociedade? Uma estabilização religiosa de dominação política até pode pertencer ao passado da Europa, mas, mesmo assim, a questão que se coloca é saber o que funciona como "Deus" em uma época de relações irrestritas de mercado. E é justamente nesse contexto de dominação descentralizada que se trata de perguntar se uma fé libertadora não precisa levar em conta justamente as linhas do êxodo, a lembrança da herança de uma tradição radicalmente humanizadora da religião bíblica.

Ateísmo no cristianismo pode continuar nos inspirando para uma crítica da religião que, simultaneamente, preserve aberta a procura por nosso "rosto revelado" (“aufgedeckten Angesicht”). No entanto, junto a isso, o próprio utópico também precisa ser refletido criticamente. Não estaria ele exposto ao perigo constante de trair o segredo humano numa ilusão completa? Um transcender pode facilmente escalar nova transcendência. E uma filosofia como a blochiana, cujos impulsos abrangem desde o Eritis sicut deus até a "transformação do mundo como todo" (Bloch, 1977, p. 303), precisa se permitir essa pergunta. Não se expressa aí um autoexagero, um pensamento de desejos sem limite, com fantasias de poder como as que também seduziram ao erro parte do movimento de 68 ?

Bloch está completamente consciente dessa problemática. O capítulo 29 de Ateísmo no cristianismo trata das fantasias cosmológicas desenvolvidas no Talmude e, antes de tudo, na Cabala de um Adão celeste (do Adão Kadmon). Nesse "grande ser humano", Deus surge numa figura humana como arquétipo de um mundo reconstituído. Makanthropos, já no Espírito da utopia é, enquanto "figura de um reino futuro", uma imagem de esperança extremamente importante para Bloch. No livro sobre o ateísmo, no entanto, ele inclui um capítulo subsequente com o título de "Também a grandeza do filho do homem desaparece; o reino é "pequeno"” (Bloch, 1977, p. 201), como se estivesse chamando à razão a si próprio.

\begin{tabular}{|l|l|l|l|l|}
\hline Qevista Dialectus & Ano 10 & n. 21 & Janeiro - Abril 2021 & p. 53 - 68 \\
\hline
\end{tabular}


Consta aí que o gigante, em relação ao qual os rabinos deliravam, seria um monstro, o "humano-confiável” não suportaria uma “expansão cósmico-celeste".

A relação tensa entre utopia humana e natural ("aut logos - aut cosmos") perpassa todo o livro. Bloch não está disposto a ver no reino natural "mero solo de vaso para nossas raízes", nem mesmo acompanha Hegel, como se a natureza fosse "um gigante cadáver dissolvido sob nossos pés" (1977, p. 228). Ele busca uma conexão do sujeito humano com um hipotético sujeito natural. Por fim, contudo, também aqui é arranjada uma certa primazia 'logos-mitológica' em relação à 'astral-mitológica'. Aquilo que diz respeito ao filho do homem requer proximidade: “o Makanthropos da mística é, por fim, pequeno” (Bloch, 1977, p. 206), não é algo que abrange o mundo todo, mas é constituído das medidas dos instantes finalmente realizados ou do 'Nunc stans' (Bloch, 1977, p. 286).

Trazer as imagens dos sonhos distantes de volta para o trabalho de efetivação do "fator subjetivo", certamente, pertence ao que há de mais significativo dentre aquilo que pode ser apreendido ao nos ocuparmos com o inventor da "utopia concreta". Ele mesmo tentou estabelecer esse elo com diferentes graus de sucesso. Quanto ao objetivo do "reino da liberdade", ele assegura: "Somente alcançável com o andar ereto, e somente preservado adequadamente na esperança daqueles que andam tanto com os afligidos e sobrecarregados quanto com os humilhados e ofendidos" (Bloch, 1977, p. 346).

Conhecidamente, o próprio Marx também só deixa iniciar o reino da liberdade para "além da esfera da produção material propriamente dita", lá onde "o trabalho deixa de ser determinado por necessidade e por utilidade exteriormente imposta". Menos atenção, no entanto, é dada ao fato de que ele fala de liberdade também nesse "reino da necessidade". E ela consiste em que os produtores associados "regulam racionalmente o intercâmbio material com a natureza, controlam-no coletivamente [...], efetivam-no com o menor dispêndio de energias e nas condições mais adequadas e mais condignas com a natureza humana" (Marx, 1985, p. 942). A luta por liberdade e dignidade na "mesa do trabalho" não precisa esperar pelo “cantar do galo gaulês", nem mesmo pela irrupção de um reino de oportunidades abrangentes de desenvolvimento humano para todos.

\section{Referências}

BLOCH, Ernst. Atheismus im Christentum. Zur Religion des Exodus und des Reichs. Gesamtausgabe 14. Frankfurt a. M.: Suhrkamp, 1977.

\begin{tabular}{|l|l|l|l|l|}
\hline Q Rovista Dialectus & Ano 10 & n. 21 & Janeiro - Abril 2021 & p. $53-68$ \\
\hline
\end{tabular}


BLOCH, Ernst. Brief an Adolph Lowe von 24/3/1968. In: Karola Bloch u.a. (Hg.), Ernst Bloch. Briefe 1903-1975, Bd. 2, Frankfurt a.M. 1985.

BLOCH, Ernst. Erbschaft dieser Zeit. Gesamtausgabe 04. Frankfurt a. M.: Suhrkamp,1977a.

BLOCH, Ernst. Experimentum mundi. Fragen, Kategorien des Herausbringens, Praxis. Gesamtausgabe 15. Frankfurt a. M.: Suhrkamp, 1977b.

BLOCH, Ernst. Geist der Utopie. Erste Fassung. Gesamtausgabe 03. Frankfurt a. M.: Suhrkamp, 1977c.

BLOCH, Ernst. O Princípio Esperança, v. I. Tradução de Nélio Schneider. Rio de Janeiro: EdUERJ/ Contraponto, 2005.

BLOCH, Ernst. O Princípio Esperança, v. III. Tradução de Nélio Schneider. Rio de Janeiro: EdUERJ/ Contraponto, 2006.

BLOCH, Ernst. Thomas Münzer, teólogo da revolução. Rio de Janeiro: Biblioteca Tempo Universitário, 1973.

CROATTO, Severino Croatto. Die Bibel gehört den Armen. Perspektiven einer befreiungstheologischen Hermeneutik. Kaiser, München, 1989.

DIETSCHY, Beat. Gebrochene Gegenwart. Ernst Bloch, Ungleichzeitigkeit und das Geschichtsbild der Moderne. Frankfurt a.M.: Vervuert Verlag, 1988.

DONNER, Herbert. Wilde Exegese. Ein Argument zum Problem der Scheinmodernität des Alten Testaments. In: Wege zum Menschen, n. 23. Göttingen: 1971, p. 417- 424.

GALEANO, Eduardo. Espejos. Una historia casi universal. Montevideo: Siglo Veintiuno, 2008.

GALEANO, Eduardo. Espelhos: uma história quase universal. Porto Alegre: LPM Editores, 2008a.

HINKELAMMER, Franz. Das Subjekt und das Gesetz. Die Rückkehr des verdrängten Subjekts. Münster: Edition ITP-Kompass, 2007.

MARTIM, Gerherd Marcel. Die Hilfe des veränderbaren Zeichens. Zu Blochs atheistischen Provokationen gegenüber der Theologie. In: Ernst Blochs Wirkung. Ein Arbeitsbuch zum 90. Geburtstag, Frankfurt am Main, Suhrkamp, 1975, p. 420.

MARX, Karl. O capital. Crítica da Economia política. Livro 03 - O processo de produção do capital. v. VI; Tradução de Reginaldo Sant’ana. São Paulo: Difel, 1985.

MOLTMANN, Ernst. Ernst Blochs Christologie. In: Bloch-Almanach, H. 23, Ludwigshafen, 2004.

\begin{tabular}{|c|c|c|c|}
\hline Q Rovista Dialectus & Ano 10 & n. 21 & Janeiro - Abril 2021 \\
\hline
\end{tabular}


STEINACKER-BERGHÄUSER, Klaus-Peter. Das Verhältnis der Philosophie Ernst Blochs zur Mystik. Marburg: Univ. Diss., 1973.

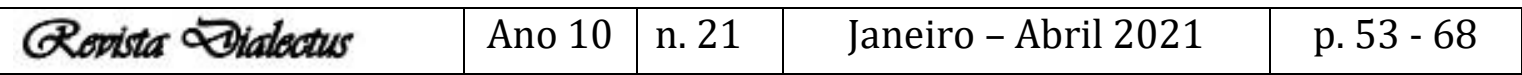

